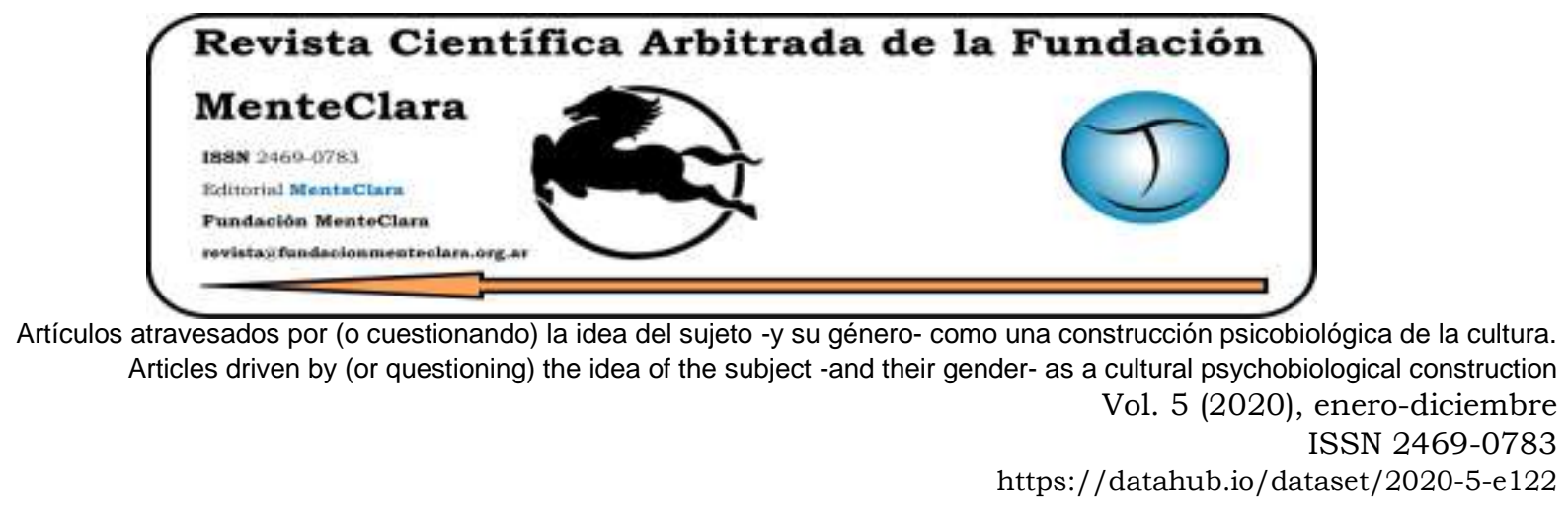

\title{
HUMAN EGALITARIANISM AND THE PATRIARCHAL ILLUSION: A PHENOMENOLOGICAL VIEW
}

\author{
IGUALITARISMO HUMANO Y LA ILUSIÓN PATRIARCAL: UNA VISIÓN \\ FENOMENOLÓGICA
}

Rudolph Bauer rbauer@rsbauer.net

Center for Consciousness Studies and Washington Center for Phenomenological and Existential Psychotherapy Studies. United States of America

Cómo citar este artículo / Citation: Bauer R. (2020). "Human Egalitarianism and the Patriarchal Illusion: A Phenomenological View». Revista Científica Arbitrada de la Fundación MenteClara, Vol. 5 (122).

DOI: https://doi.org/10.32351/rca.v5.122

Copyright: (C) 2020 RCAFMC. Este artículo de acceso abierto es distribuido bajo los términos de la licencia Creative Commons Attribution 4.0 International License (CC BY 4.0). Recibido: 03/12/2019. Aceptado: 11/12/2019 Publicación online: 06/01/2020

Conflicto de intereses: None to declare.

\begin{abstract}
This is a phenomenological study about the Ontological Basis of Egalitarian Life. The foundational source of Egalitarian Life is the experience of Equality Consciousness and Equal Vision. The basis of Equality Conscious and Equal Vision is our direct experience of the Purity of our Being and the Being of Others. Equality Consciousness is not simply a mental value but a direct perception of the Purity of Being of all men. Our experience is that all men are created equal is not simply a belief but our experience of our direct knowingness of the Being of human beings. The study also enters into the phenomenology of the Patriarchal Master as the One who knows Absolutely with the corresponding experience of domination and submission, also known as the master slave relationship. The Patriarchal Institution whatever the circumstance destroys Equality Consciousness and Equal Vision and ultimately destroys Egalitarian life.
\end{abstract}




\section{Resumen}

Este es un estudio fenomenológico sobre las bases ontológicas de la vida igualitaria. La fuente fundamental de la vida igualitaria es la experiencia de la conciencia de igualdad y la visión de igualdad. La base la conciencia de igualdad y la visión de igualdad es nuestra experiencia directa de la pureza de nuestro ser y el ser de los demás. La conciencia de igualdad no es simplemente un valor mental sino una percepción directa de la pureza del ser de todos los hombres. Nuestra experiencia de que todos los hombres son creados iguales no es simplemente una creencia sino nuestra experiencia del conocimiento directo del Ser de los seres humanos. El estudio también explora la fenomenología del Maestro Patriarcal como aquel que conoce la Verdad Absoluta con la experiencia correspondiente de dominación y sumisión, también conocida como la relación maestro-esclavo. La Institución Patriarcal, cualquiera que sea la circunstancia, destruye la Igualdad de Conciencia y la Igualdad de Visión y, en última instancia, destruye la vida igualitaria.

Keywords: Tantra; Phenomenology; Egalitarian; Equal Vision; Equality Consciousness; Lacanian Psychoanalysis; Existential Psychoanalysis; Purity of Being; Direct Perception; Gnosis; Patriarchal Master

Palabras Claves: Tantra; Fenomenología; Igualitario; Visión igualitaria; Conciencia de igualdad; Psicoanálisis lacaniano; Psicoanálisis existencial; Pureza del ser; Percepción directa; Gnosis; Maestro patriarcal 


\section{Introduction}

The Heart of Egalitarianism is our ongoing experience of the Purity of Being of our self and the Purity of Being of the self of others. This presence of the Pure Being-ness of humanness is located in all the various forms of human beings. Both the good and the bad, the kind and the evil, the beautiful and the ugly, the smart and the ignorant, the happy and the sad, those of good fortune and those of tragic fortune, those who are believers and those who are non-believers! The Purity of our Being is beyond our mind and the judgements of mind. Our mind cannot experience Being, only our awareness directly knows Being.

\section{The Purity of Being}

This presence of Being is completely Pure. This presence of Being is the Purity of the ontological openness of Being-ness, as well as the Purity of the open radiance of Being-ness. Our mutual experience of the pervasive presence of Pure Being-ness that is within each other, brings forth the Egalitarian Field of human existence. Our mutual experience of the pervasive presence of Pure Being-ness that is within each other brings forth Equality Consciousness and Equal Vision.

Equality Consciousness and the experience of Equal Vision is the experience of the Purity of Being, being within 'us as us' and the Purity of Being being experienced within each other. Equality consciousness and the experience of Equal Vision is the source of self- liberation.

\section{Foundational Base of Egalitarian Experience}

Our mutual experience of the pervasive presence of Pure Being-ness within each person brings forth the Egalitarian field of Existing-ness. 
From within the ontological field of mutual resonance and mutual attunement to the Pure Being-ness within each other, the power of the Egalitarian field of Being manifests as a social political experience. The ontic social political Egalitarian field of Being is ontologically grounded in our awareness of our mutually experienced Purity of Being. This experience of the Purity of Being of human beings is the existential foundational base of Egalitarian social political experience.

Without this existential foundational experience of Being and the Purity of Being, we would be living only in opinion and only in belief. Egalitarianism becomes nothing than one more opinion and one more ardent belief. Actually the personal experience of Egalitarianism reflects the foundational experience of the Purity of Being of human beings. To experience of the Purity of Being of and within human beings is self liberating. To live within the Purity of Being within the Sea of Being is self- liberating.

\section{Ontological Ontic Dimensions: An Intertwining}

Ontic is the actual physical and psychological dimension of a human being. Ontological is the Being dimension of a human being. Human beings are the intertwining of the ontic ontological dimensions. Through our direct awareness of the ontological dimension of human experience, there is the experience of the indivisibleness of the sameness of Being within all of human beings. And through our direct intuitive knowing of Being, there is within our direct experience of Being the sense of the indivisibleness of the Pure Being-ness of the Being of human beings. 


\section{Egalitarian Experience}

From this experience of the Pure Being-ness of our Being and the Being of other human beings there naturally arises the Egalitarian Experience of Equality consciousness and Equal vision. In this context, Egalitarian Experience is contextualized ontologically and ontically. From within this ontological experience of equal vision and equality consciousness, the ontic political and social field of Egalitarianism can be manifested and perhaps sustained and maintained. Ontic reflects the actuality of our mind's knowing of forms. Ontological reflects our awareness directly knowing Being. We are ontic ontological human beings.

\section{Direct Perception of Being}

The experience of Egalitarianism reflects our natural direct perception of Being. The experience of Egalitarianism reflects our direct perception of the Purity of Being of human beings. This experience of ontological equality is not simply an opinion or a good idea. Jacques Maritain the contemporary French Catholic philosopher called this direct intuitive knowing of the Being of a human beings Connatural Knowing (Koppl, 2008).

One of earliest description of the direct experiential knowing of Being was expressed by the Pre-Socratic philosopher Heraclitus in the $5^{\text {th } \mathrm{BCE}}$ century.

\section{Natural Perception of Being}

This understanding of the natural direct perception of Being is deeply embedded within medieval Thomistic philosophy and theology. This natural direct knowing of Being is also understood and embraced in the 
Continental Phenomenology of Martin Heidegger and Maurice Merleau Ponty (Morris, 2018). This direct intuitive knowing of Being also reflects the understanding and the experience of Bersonian philosophy. In eastern philosophical Non Dualistic traditions such as Tibetan Dzogchen and Hindu Kashmir Shavism, this natural direct perception and direct knowing of Being and the Being of beings is called Jnana or Gnosis. Dudjom Lingpa the founder of the Dudjom lineage of Tibetan Buddhism would describe Dzogchen as the training to directly experience the Purity of Being of all persons and the Purity of Being of all phenomena (Lingpa, 2015).

In contemporary Existential Psychoanalysis and Existential Psychotherapy the experience of direct knowing of Being has been taught by such psychotherapist as Donald Winnicott, Robert Stotorow, Erving Polster, Miriam Polster, Austin DesLaurier, Eugene Gendlin, Michael Eigen, Menard Boss, Rollo May, Carl Rogers and many, many others. In this existential context, the direct experience of the field of Being is the direct experience of our ontological sense of our relational self in relationship to human beings and their Being-ness (Morris, 2018).

\section{The Inner Experience of Being}

Within human beings there is this innermost awareness of the inner experience of Being. St. Augustine in the $6^{\text {th ad }}$ century writes about this innermost knowingness of Pure Being as self. This experience of inner Being is completely Pure. The forms of human beings are so completely different and their characters are so completely different, and yet their field of Being is completely Pure and untouched and uncontaminated.

From within this mutually perceived field of Pure Being, Egalitarian existence can validly emerge and become social political egalitarian life 
systems. Egalitarianism is an authentic state of direct knowing of Being. It is not simply a mind alone value. It is not a transcendental principle. It is not a good or new idea. It is not revealed by whomever. The purity of Being is self- revealed by Being itself within Being itself to Being itself 'as us'.

The unbound infinity of human cultures are so vastly different and yet the Being of all human beings are of the very same Being as our own Being. This Being is always completely Pure and Luminous. This sameness of Human Being-ness is the source of Equal Vision and Equality Consciousness. This "sameness" of our mutual experience of the Purity of Human Being-ness is the ontological source of Egalitarianism. From within this mutually held ontological experience of mutually held Purity of Being political and social systems can become manifest as Egalitarian life systems.

\section{The Sameness of Being: Univocity}

The Equality of the sameness of the Being of human Beings is the realistic existential source of Equality Consciousness and Equal Vision. Equality Consciousness is the true and ultimate source of ethical experience, ethical understanding and ethical action. Equality consciousness is the path of self-liberation. Equality Consciousness does not depend on religious belief or religious institutionalization, or religious understanding. Equality consciousness does not depend on patriarchal authority. Equality consciousness does not depend on the One Who Knows Absolutely. This sameness of Being was described by Dun Scotus and Meister Eckhart, Spinoza and Deleuze as Univocity. The sameness of Being is beyond the analogy of Being. The analogy of Being thinking is ultimately a Patriarchal assumption. 


\section{View of Existential Phenomenology}

From the view of Existential Phenomenology, all human beings have direct knowing of Being. All human beings have gnosis and jnana. All human beings are gnosis and are jnana. Human beings do not simply have direct knowing, they are the direct knowing of Being. This natural view is neither understood or experienced by transcendental traditions both of the east and the west. This phenomenological view was especially articulated both by Maurice Merleau Ponty and Martin Heidegger in their transformation from a transcendental phenomenology into a perceptual ontology of direct perception of Being. Phenomenological tradition profoundly shifted from a Transcendental tradition to a tradition of Immanence (Capobianco, 2014).

\section{The Two Modes of Human Knowing: The Knowing of Mind and The Knowing of Awareness}

This skill and capacity of direct knowing of Being can and must be practiced and cultivated. We have two modes of knowing. Our mind knows form and our awareness knows Being. Our mind knows duality and difference. Our awareness knows non duality and oneness. In developing our skill of knowing as knowers of Being we must learn to integrate our knowing of mind into and within our knowing of awareness. In this way we can know the Being of forms and the form of Being. We can know the Being of phenomena and the phenomena of Being.

This integration of the two modes of knowing is the natural path of self- liberation. In this way we can experience the non-duality of Being within the duality of beings and within the duality of beings we can experience the non -duality of Being. This is self- liberation through 
circumstance and events of our life. This is self -liberation by living in awareness of field of Being.

In the great Dzogchen tradition of immanence, the distinction between mind and awareness is considered to be most important. This distinction initially took place in the $8^{\text {th }}$ ad century in Tibet. Sems and Semde were understood to be the two fundamental ways of knowing. Sems was the knowing of mind and Semde was the knowing of awareness. This distinction will be elaborated throughout this text (Karunda, 2018). This same distinction is of great importance in contemporary continental phenomenology and in contemporary experiential psychoanalysis.

\section{Non Conceptual Knowing}

The experience of the Being and the Purity of Being is not necessarily a reflective conceptual experience. The conceptual reflective experience would be of our mind reflecting on the direct knowing of our awareness directly knowing Being and the Purity of Being. The direct knowing of our Being and the direct knowing of the Purity of our Being is the direct knowing of our awareness which is non-conceptual and intuitive. Sometimes this knowing is just a "knowing" and sometimes this knowing is a felt sense, sometimes this knowing is an experience of direct knowing as our field of Being changes within us and around us.

\section{Multidimensional Knowing}

This direct knowing can be vast, multidimensional and infinite in its horizons. Sometimes our direct knowing is knowing Being and Pure Being through the ordinary phenomena of the world, the ordinary phenomena of events, and the ordinary phenomena of human beings that inhabit our world. The light of our awareness field opens into the light of 
phenomena and the openness of phenomena. The light of our awareness opens into the Being-ness of phenomena and then the phenomena of Being-ness itself.

Sometimes our awareness which is multidimensional opens for us to experience the archetypal dimension of Being. This is the dimension of the primordial energies, the alchemical elements and the powers of archetypal manifestation. In manifestation, these energies, elements and archetypes become our ordinary life world. Sometimes this dimension is articulated in the archetypal language of deities and dakinis. Sometimes this dimension is articulated as quantum particles and vortices which reflect the language of the science of physics.

And sometimes our awareness which is multidimensional opens for us the foundational experience of the potential space of Pure Being, Pure Potentiality, Pure openness, Pure luminosity, Pure source, Pure ground of Being. All these three dimension are within the immanence of Being, the pervasiveness of Being. Being is not a being, but Being self-manifests as all beings, including you and I'.

\section{The Drama of The Absence of Direct Knowing of Being}

In the Buddhist Transcendental tradition and transcendental culture there is an absence of the Direct Knowing of Being. More specifically, there is the absence of the Direct Knowing of Awareness Knowing Being. There is only the knowing of mind knowing form. There is no recognition of the knowing of awareness knowing Being. There is little recognition that human beings have these two ways of knowing. 


\section{The Two Ways of Knowing}

The knowing of the mind knows form and the knowing of awareness knows Being. The mind only knows form. The mind knows duality. The mind knows difference. The mind knows things and entities. The mind knows through thoughts, through feelings, through sensations, through memories and imagination. The mind lives by the judgements of right and wrong, good and evil, better or best and truth and falsity.

The knowing of awareness directly knows Being. The knowing of awareness knows non-dualistically. The knowing of awareness knows oneness. The knowing of our awareness knows the formlessness of Being. Our awareness knowing Being, compliments our mind knowing form. The integration of the mind knowing form and awareness knowing Being is very important for the unfolding of self- liberation in the world of appearance and phenomena.

\section{Integration of Mind within Awareness}

The knowing of form can be integrated within the field of awareness knowing Being. Within the integration mind knowing form and awareness knowing Being, we can know the Being of form and the form of Being. We can know the Being of phenomena and the phenomena of Being. Without our being able to access our innermost field of awareness our direct experiential knowledge of Being is foreclosed. In this loss, we would lose our experience of Pure Being and the Being of the world. We would lose the natural medium of self -liberation through our Being in the world. The path of self -liberation is through our Being in the Being of the world. Being, in Being itself is the path of Immanence. 


\section{Prejudice Against Phenomena and Being of Phenomena}

Buddhist Transcendental traditions and the transcendental culture have a prejudice against our direct knowing of awareness knowing Being. The transcendental traditions also have a prejudice against our knowing of the Being of phenomena and phenomena of Being. Our knowing of Being through the open doorway of luminous phenomena is foreclosed within Transcendental Buddhism. The phenomenological knowing of embodied Being is foreclosed. This prejudice against the knowing of awareness and the knowing of phenomena is discussed in detail in the first phase of this paper.

Buddhist Transcendental traditions do experience that the mind can know the forms of phenomena. Yet for the Buddhist Transcendental traditions our minds can become locked into phenomena and the density of phenomena. Thus phenomena can conceal and hide the reality, the actuality of Transcendental Being or Transcendental Reality. The Transcendentalist mind can only know the form of phenomena. For the Transcendentalist beyond the form of phenomena or within the form of phenomena is to experience emptiness and absence and void-ness. For the Buddhist Transcendentalist within the form of phenomena there is only emptiness or void-ness or absence of Being.

For the Buddhist transcendentalist, rather than phenomena being the very manifestation of the light and the embodiment of pure Being; the Transcendental traditions experience phenomena as being an empty of Being. The Being of phenomena and the phenomena of Being is considered a personal illusion and cultural illusion. For the Buddhist transcendentalist, phenomena is without Being-ness. The Transcendental experience of phenomena is that Phenomena is empty. Empty of what? Empty of Being? 


\section{Incomplete View}

This view about the emptiness of phenomena is the result of phenomena being viewed by our mind alone. Only the form of phenomena is experienced. The Being of phenomena is not known or experienced in Transcendental Buddhism (López, 2012). From the phenomenological view, our mind only knowing form is incomplete knowledge. When mind knowing form is integrated into our awareness knowing Being, then the complete experience of phenomena, and the Being of phenomena can be simultaneously experienced and understood. Again, this path of the integration of mind within awareness is the path of immanence.

\section{Path of Immanence within Buddhism}

In the unfolding of the different epochs within Buddhism there are paths of immanence. Through the ancient Nyingma tradition of Tibetan Buddhism Dzogchen entered Tibet in the $8^{\text {th }}$ ad century and earlier. Dzogchen is a path of immanence. In the $8^{\text {th ad }}$ century, Dzogchen the distinction of Sems meaning mind and Semde meaning awareness was a most essential distinction made in regards to our two ways of knowing. Sems is the mind knowing form, and Semde is awareness knowing Being. This same fundamental distinction of the two ways of knowing is made in contemporary continental phenomenology and contemporary existential psychoanalysis (Longechen, 2015).

There were also much earlier forms of Dzogchen in Tibet that were formulated by Bon culture. The Bon culture was a most ancient shamanistic culture in Tibet long before the Buddhist culture. In time, the Bon culture integrated Buddhism into its shamanistic practice and 
culture. In the Bon tradition these two ways of knowing were understood and practiced in the embodied art of Dzogchen.

In the later unfolding of the Vajrayana Tantric path in Tibetan Buddhism there emerges a transitional stage of the merging of transcendental philosophy and philosophical immanence. This mingling and merging varies both through time and through the emphasis of the various religious traditions within Tibetan Buddhism. The Nyingma tradition in its very beginning involved an emergence of experience of both transcendence and immanence. The Chakrasamvara Tantra is a magnificence example of a dynamic Tantra that is inclusive of transcending the nature of phenomena and simultaneously experiencing the Beatific-ness of embodied Being. The Guhyagarbha Tantra is another such Tantra.

\section{Bliss Overcomes Suffering}

The Tantric Vajrayana theme that Bliss overcomes suffering was a source of the integration and co-emergence of the transcendental immanence interface. As Tantra unfolded there was a movement from dissociation and detachment of transcendental philosophy into the embodiment and the embracing of phenomena and the Being of phenomena in philosophical immanence.

The actual interface of the transcendental immanence was much less explicit in the historical unfolding of the new translation traditions. The new translation traditions maintained greater emphasis on the Transcendental dimension of the actuality of Tantric life and experience. This interface of transcendence and immanence within the Tantras is often unarticulated. The explicit relationship between the knowing of 
mind and the knowing of awareness in Vajrayana is often not explicitly articulated.

\section{Distinction of mind and awareness}

The distinction of mind and awareness is of fundamental importance in the phenomenology of the two ways of knowing. When our mind knowing form is integrated within our awareness knowing Being, then the complete experience of phenomena and the Being of phenomena can be experienced simultaneously. This union of mind and awareness is understood and acted upon from within this base of human knowing.

\section{Emptiness of Form and Emptiness Beyond Form: Transcendental Reality}

The knowing of Mind alone without the integration of mind into our awareness field will result in the experience of the emptiness of form and the emptiness beyond form. Our own experience of form without the base of awareness is Being-less Emptiness. When the knowing of our mind knowing form is integrated within our awareness knowing Being, we can experience the Being of form and the form of Beings. To experience Being through form or to experience Being through phenomenological experience is self- liberating.

\section{Guatama Transcendental View: A Mind Alone View}

Guatama's view $6^{\text {th }}$ BCE century of phenomena was with his mind alone. This was an incomplete view of human knowing in $6^{\text {th } \mathrm{BCE}}$ and is still now in our current time the knowing of mind alone is an incomplete view of human knowing. 
Guatama brought forth the transcendental view of phenomena with the knowing of his mind alone. There was no direct knowing of awareness knowing Being. Guatama's experience of knowing only through his mind was Being-less emptiness. The early transcendental view of knowing form through mind alone was incomplete and the transcendentalist worked skillfully within this incompleteness.

Guatama worked with the incompleteness by transcending the incompleteness of mind experience and by going beyond phenomena and going beyond the phenomena of the mind. By going beyond phenomena of mind he experienced self- liberation by entering transcendent reality or transcendental Being.

The way the Buddhist transcendentalist work with their experience of phenomena and the emptiness of phenomena and the void-ness of phenomena is to leave phenomena behind and go beyond phenomena. Transcendentalists dissociate from their experience of phenomena, and they eventually completely detach their mind, from all phenomena and all appearance of phenomena. They then detach from their mind as the mind only knows duality.

\section{Beyond The Mind}

What remains is Transcendence and the actuality of Transcendence, Pure Transcendence. This is a form of self- liberation that is beyond phenomena and phenomenological experience. This form of selfliberation is beyond the mind.

The transcendentalist even detaches and dissociates from the phenomena of their own mind. In this dissociative approach to phenomena, and the world of phenomena, they are thereby free to transcend phenomena, transcend the experience of phenomena, and 
transcend into transcendental reality or transcendental Being. Transcendental Being is Pure Being as Pure Source.

This knowing is a kind of let me "out of here" approach to human existence.

\section{Immanence and The Being of Phenomena and The Phenomena of Being}

The Tradition of Immanence, is a tradition of Liberation through the Direct Knowing of Being and the Direct knowing of the Being of phenomena and the Direct knowing of the phenomena of Being. The traditions of Immanence such as Tibetan Dzogchen, Somatic Forms of the Tantric Vajrayana, Hindu Kashmir Shavism and Contemporary Continental Existential Phenomenology all integrate their knowing of mind within their knowing of the field of awareness. The field of awareness is the field of Being. These traditions of immanence are open to the phenomenological experience of Being. These traditions of immanence are a phenomenological approach to the direct experience of Being.

The traditions of immanence are traditions that know and acknowledge the important distinction of two ways of knowing. They know the mind knows form and knows difference and the mind knows duality and knows separateness. They know their awareness knows Being, and their awareness knows non duality, and their awareness knows oneness. 


\section{The Path of Equality Consciousness and Equal Vision: The Purity of Being}

Within the context of immanence a person can know that by integrating their mind into awareness, they can know the Being of Phenomena and the Phenomena of Being. Self-Liberation happens by living within and through the Being of Phenomena of the world which is Being itself and which Being is completely Pure. To see and experience the Purity of our Being and the Purity of the Being of others is selfliberation. This experience of knowing the purity of Being of oneself and the purity of the Being of the another person is the source of Equality Consciousness and Equal Vision. The path of immanence is the path of self -liberation through Equality Consciousness and Equal Vision.

\section{Phenomenological Immanence}

In these tantric traditions of phenomenological immanence, we experience all phenomena and all appearance of phenomena as the selfmanifestation of Being, as the luminous Being-ness of phenomena. And we experience that all phenomena and all appearance are the forms of the radiant light of primordial awareness, the primordial ground of Being. All phenomena and all appearance are the self-manifestations of Pure Being. All phenomena and all appearance are Pure luminous Being embodied. All phenomena are the embodiment of Being, and the embodiment of the Purity of Being.

\section{The Purity of Being As Path}

You and I are Being and we are the Purity of Being. This purity of Being is a given. The purity of our Being is not what we think or how act or what we eat or how we feel. The purity of Being is the very given-ness of 
our Being. We can integrate everything absolutely everything into the Purity of our Being. This integration of experience into the Purity of our Being liberates everything. Our experience of the Purity of our Being and the Being of another is the source of Equality Consciousness and Equal Vision. In the traditions of immanence self- liberation known through the experience of Equality Consciousness and Equal Vision.

Our knowing through our Direct and Immediate Awareness allows us to directly know the Being of phenomena and the Phenomena of Being. This knowing of the phenomena of Being allows us to experience the Purity of Being of our self and the Purity of Being of another. This is the path of self- liberation just as we are, in the immediacy of our life circumstances and life events. Phenomena are experiential pathways and open experiential doorways for our experiencing the Being of beings and the Purity of Beings.

This Path of Self-liberation happens through the our experience of the Purity of Being of our own Being and the Purity of Being of everyone. We can go further and experience the Purity of all Phenomena. This experience of experiencing the Purity of Being of all phenomena is possible for everyone. We simply use our two ways of knowing simultaneously as we live within the unfolding events of life.

This direct knowing of awareness is in everyone and this direct knowing of awareness is a given in everyone. Yet this experience of our awareness of our awareness, is definitely for many is hidden. When the experience of awareness is hidden, then the path of Equal vision and Equality consciousness is hidden. Of course, there are many different paths of self- liberation. The path of Equality Consciousness and Equal Vision is not for everyone. The path of Equality Consciousness and Equal Vision is the most direct path of self-liberation. 


\section{Knowing Being and Knowing The Purity of Being: Foundation for} Egalitarian Life

Every person who is in the field of their own awareness can know the Being of their own Being and can even know the Being of the another

person. And every person can experience the Purity of their own Being and the Purity of the Being of another. This experience of the mutually held field of Being as the Purity of Being is Equality Consciousness and is Equal Vision. This experience of experiencing the mutually held field of Being is foundational for the manifestation of Egalitarian Social and Political life. This ontological understanding about Egalitarian Social and Political life is foundational.

\section{Egalitarian Social and Political Life}

We, as most ordinary people can experience Equality Consciousness and Equal Vision by experiencing the Pure Being within our self and the pure Being of the another Person. This Equality Consciousness and Equal Vision brings forth authentically and naturally the experiential realm of Egalitarianism into the Social Political world of reality. Truly all men are created equal is not simply an intellectual assertion but reflects our direct ontological experience of each other as The Purity of Being.

\section{The Drama of Primordial Guru and The Patriarchal Master Who Knows Absolutely}

In the context of Lacanian symbolization, there is the Symbolic Personification of the Patriarchal Master as the One who Knows Absolutely. This theme of the Patriarchal Master as the One who knows absolutely is a major focus of Hegel's great text The Phenomenology of Spirit. The focus of the text is on the domination of The Patriarchal 
Master and the required submission to the Patriarchal Master who is the One who knows absolutely.

\section{Disruption of Egalitarian Social and Political Life}

In the Patriarchal Tradition there arises naturally the Master Slave struggle with the authoritarian Master who knows absolutely. This is the drama of domination and submission. This is not the realm of Equality Consciousness or Equal Vision. The Patriarchal Master Tradition disrupts the ontological foundation of Egalitarian life. The Patriarchal Master tradition does not existentially support Equality consciousness or Equal Vision and neither does The Patriarchal Master Tradition support Egalitarian Social and Political life. The Patriarchal Master tradition is essentially Lordship and Bondage.

\section{Ontic Ontological Relationship and Pre Reflective Subjectivity}

There is ontic ontological relationship between our mind's ontic knowing of the form, and our awareness knowing of ontological Being. Our mind knows the ontic form of the Patriarchal Master as the One who knows absolutely, and our awareness can experience the ontological Being-ness of Pure Being of human beings. On the level of the mind there is the knowing of the forms of persons such as the person of Patriarchal Master who is the One who knows Absolutely.

On the ontological dimension of experience within the openness of our awareness -Da Sein-, we can directly experience the primordial presence of Being. We can experience the Being of our own being as well as the Being of other beings. We can also experience the primordial qualities of Being. A quality of Being that is self-liberating is the quality of selfrevelation of Being within our own self as well as within the Being of the 
world. This quality of self- revelation is in eastern philosophical traditions called the Guru. The Guru is also the quality of the selfmanifestation of Wisdom Gnosis or Wisdom Knowingness. In Western phenomenology this quality of self- revelation is called the logos as well as Alethea.

This experience of our own primordial awareness is described by some contemporary phenomenologist as "pre-reflective subjectivity." Prereflective subjectivity is our experience as primordial awareness. Within our own pre-reflective subjectivity the field of Being manifests with its different qualities of open spaciousness, vital energy, luminous radiance, compassionate manifestation and pure knowingness of our multidimensional Being. Within our pre-reflective subjectivity we also can know directly the presence of the Guru or the presence of the selfrevelation of Being within our self, as well as within the world. To attune our self to this unfolding presence of luminosity as the Guru is selfliberating.

\section{Symbolic Function of Patriarchal Master of The Ordinary Life}

\section{World}

The French psychoanalyst Lacan would describe the Symbolic function of the Patriarchal Master as the Phallic Name of The Father (Slavoj, 2006). The Patriarchal Master contextualizes the Patriarchal Social Political System in what Husserl would call the Ordinary Life World.

On the ontological Level we can experience our direct awareness knowing Being and our immediate direct non conceptual knowing experiencing the light and presence of the formless Being. This direct sense of formless Being is also what eastern philosophy names as the 
formless guru. The formless guru is the field of luminous Being. In the language of our field of innate awareness the energies and the luminous qualities of Being are experienced and felt as wisdom knowing and as wisdom gnosis. This experience of the wisdom qualities of Being are manifested within our direct experience of Being.

This experience of our wisdom nature and wisdom qualities of Being are the manifestation of Being within own pre-reflective subjectivity. The Being of our own awareness is the direct knowing of our own Being in its Purity, our own Being in its Spaciousness, and our own Being in its Wisdom Energy and Radiant Light. The Being of our awareness is intrinsic as our innate sense of self, and innate sense of ongoing continuity of Being. We are ontic ontological Beings.

\section{Primordial Guru as Being and as Logos}

The Primordial Guru is the essential quality of Being that self- reveals itself as the Luminous Being of everyone, within everyone, and within all phenomena. The Guru is the infinite process of self-revelation and selfmanifestation of Being in the Being of beings and the Being of the world. The Guru is the self-manifestation and self- revelation of Pure Being. This revelation process of Being is in the language of ancient Greek philosophy and as expressed by Heraclitus is the Logos.

In the language of eastern philosophy this revelation process of Being is the "Guru". The Guru is not an entity or a person, the Guru is Being's ongoing self-revelation unfolding. The Guru is the Logos, and the Logos is the Guru. To experience the Guru is to experience the unfolding process of self-liberation. 


\section{The Heart of Being}

The Guru is power of our direct knowing of Being and the direct knowing of the Purity of Being. The Guru is this power of Being that is within every person as their very innermost self. The Guru is our Being's knowing of Being. The Guru is our direct knowing of Being. The Guru is the Heart of Being. The Guru is the direct knowing of the Purity of our own Being and the Purity of the Being of others.

The Guru is the source of Equality Consciousness and Equal Vision. The Guru is the source of self- liberation. The Guru is the source of truth as Alethea. The Guru is the ontological source of Egalitarianism in social and political life.

The Patriarchal Master Tradition is structurally destructive of Egalitarian social and political life. The Patriarchal Master tradition of the One who knows absolutely is intrinsically in opposition to the Primordial Ontological Guru and the self-manifestation of the Guru.

\section{Intrinsic Conflict}

There is an intrinsic conflict between the power of the innate Guru and the power of Patriarchal Master who knows absolutely. The power of the ontological guru is the ontological source of Egalitarian social and political life as well as the source of Equality Consciousness and Equal Vision. The Patriarchal Master is the One who knows absolutely. The Patriarchal Master requires obedience and devotion. Hegel in his text phenomenology of spirit says that The Patriarchal Master who knows absolutely, brings forth lordship and bondage, and the drama of domination and submission. This is for us is a direct conflict between the unfolding power of the universal Guru as the revelation of Being, and the power of the Patriarchal Master who knows absolutely and politically 
manifests the drama of domination and submission. Hegel calls this drama the Master Slave relationship.

This lordship bondage drama is in clear contradiction of Equality Consciousness and Equal Vision that the primordial ontological guru continually self-manifests. The tradition of the guru and the tradition of the Patriarchal Master are in complete opposition to each other and can intrinsically negate of each other. The power of the ontological Guru and the power of the Patriarchal master are intrinsically ambivalent and contradictory of each other.

The knowledge of the Guru is the knowledge of our awareness knowing formless Being. The knowing of our mind knowing form cannot directly know the formless Guru. Our mind can have thoughts and ideas about the Guru but our mind does not directly know or experience primordial Being as the Guru. Our direct open awareness -Da sein- experiences Being and the experience of the self-revelation of Being and manifestation of Being as the Guru. Our direct open awareness -Da sein- can directly experience the guru as our own Being. In fact our direct open awareness - Da sein-can experience the guru as our own Being and as our own inner self. This is natural capacity and power for self-liberation through the circumstances and events of our life.

Our mind can know the Patriarchal Master -who has absolute knowledge- who brings forth within our ordinary life world the Patriarchal world that is social, that is political, that is spiritual and that is cultural. In many eastern philosophical and religious traditions many think that the Patriarchal Master is also the Personification of the Guru. This thought that the Patriarchal Master is the Guru and the Guru is the Patriarchal master is a thought and this thought becomes a belief. This understanding does not reflect the direct perception of Being, and does not the direct perception of the Guru. This thought is a belief, a cultural 
belief. The Guru and the Patriarchal Master as the One Who knows Absolutely are in Existential opposition.

\section{The Power of Self Illumination and the Self Illusion of Omnipotence and Omniscience}

The Guru is not an entity. The Guru is not a Person. The Guru is the cosmological ontological power of self- illumination and self-liberation. The Guru is the power of Gnosis and the power of Jnana. Gnosis is the direct perception of the Being of beings including our own being. Jnana is the Direct Knowingness of the Being of beings and Being of our own being.

\section{Equation of Power of Guru with the Power of Patriarchal Master}

Our cultural mind does not know Being. The cultural mind only knows form of beings. The cultural mind of many eastern philosophical and spiritual traditions equates the power of the Patriarchal Master with the Power of the Guru. Their cultural mind conceives of the Guru as a Person of power and authority and absolute knowledge. They further think that the Patriarchal Master is a person of power and authority and absolute knowledge. So this thinking is that the Guru is the Person who is the Patriarchal Master who knows absolutely.

This is not true. The Guru is not a person. The Guru is not a Patriarchal Master who knows absolutely. The Guru is not a form or an entity. The Guru is the self- illuminating power of Being. The Guru is the power of Self-manifestation of Being. The Guru is the power of our innate radiant luminosity of our human awareness, and our power of our light to metabolize all experience. The Guru is the light of awareness, the Guru is the light of Being, and the Guru is the radiance of Being. The 
Guru is the Trans-lucidity of Primordial Awareness that opens and brings forth the Trans-lucidity of phenomena. The Guru is not an entity. The Guru is not an entity. The Guru is not a being. The Guru is not a person. The Guru does live within all human Beings.

Our direct experience of the Guru is a path of Self liberation. The Guru is our very own innermost self as the Being of awareness. The Guru is wisdom gnosis or wisdom knowingness. The Guru is ontological expression and ontological manifestation of Being as the Logos. The Logos is wisdom knowingness. The Guru is wisdom knowingness. Wisdom knowingness is the direct knowing of Being and the power of the self- manifestation of Being. The Guru and the Patriarchal Master are not on the same level of phenomenological discourse.

\section{Guru Patriarchal Bewilderment}

Many people and many eastern philosophical traditions may blend the experience of The Guru and the experience of Patriarchal Master as being the same experience and same Person. Many eastern philosophical Traditions project the Guru as being a singular person and the very same Person is also the Patriarchal Master who knows Absolutely.

Many eastern traditions personify the Guru as a singular human being. They consequently imagine that Guru and the Patriarchal Master are the same person. The Patriarchal tradition of the one who knows Absolutely is definitively hierarchal, definitively constructed on the status of above and below, superior and inferior, and the one who knows status and those that do not know status. The patriarchal traditions are obsessed with the impurity of mind, the earning of merit, the submission by obedience, and the necessary for a dissociative approach to phenomena, and our cessation of mind. The Patriarchal Master tradition 
is most often a political expression of the transcendental philosophical tradition.

Some Tibetan Buddhist traditions consider that the Guru and the Patriarchal Master are always the same person. If you are the Patriarchal Master who knows absolutely then you are the Guru. And if you are the Guru, then you are the Patriarchal Master who knows absolutely. This popular and traditional understanding is simply not the truth of the Ontological Guru. This form of understanding does not express the nature of the Ontological Guru. The Guru is a dimension of Being and not a dimension of our personal psychology as cultural mind. "The Guru is not an old man with a beard" as the Shaivite Master Swami Muktananda would so often say.

\section{The Essential Contradiction}

This understanding of the Guru as the Singular Personal Patriarchal Master is a direct contradiction of the truth of the universality of the ontological Guru. This limited and limiting understanding and experience of the Guru is a contraction of the truth of the nature of the Guru. The Guru is not the possession of single person or a single lineage or a single tradition or even a single culture. The Guru is a universal dimension of Being that is within all human beings. Even within you and I as we read this paper.

The Patriarchal Tradition does not own or possess the Guru. The Patriarchal Master tradition as Hegel describes in 'The Phenomenology of Spirit' is a tradition of Lordship and Bondage, of domination and submission, and ultimately a form of the Master Slave Relationship. Hegel and his great commentator Kojeve makes most explicit that many spiritual and religious paths located in the Patriarchal Master tradition 
are paths of the Master Slave relationship, paths of domination and submission (Jeff, 2018). These are paths of obedience to the Patriarchal Master. These are paths of liberation through obedience and submission.

Our mind knows form and the form of beings. Our mind knows duality. Our mind knows right and wrong, good and evil, better and best, truth and falsity. Our mind makes judgmental statements about the truth of phenomena. Our mind knows the form of the Patriarchal Master as the One who knows absolutely. Our mind may experience the Guru as a singular being. Our mind may experience the drama of domination and submission and consider such experience as the path of selfliberation. Many contemplative religions reflect this lordship bondage drama with the characteristic of the drama of domination and submission.

Our mind does not experience Being. Awareness experiences Being and the Being of beings. Our mind does not directly know the formless Guru. Our state of open awareness -Da sein- can know the formless presence of Being as the Guru and the Guru as the Power of Being's selfmanifestation.

Our awareness knows Being. Our awareness knows oneness and our awareness knows non- duality. Our awareness experiences the presence of the guru as the presence of Being and the self- illumination of Being. The form of the Patriarchal Master is ontic knowledge. The experience of the Guru is the presence of Being as wisdom gnosis. The Guru is our ontological knowing of Pure Being. Many religions and many traditions are bewildered by the confusion of the Guru being a person who is patriarchal and who thinks they know absolutely. 


\section{No One Owns The Guru, No One Possesses The Guru}

The Guru does not belong to any one tradition or any one person or any one culture. The Guru is a primordial quality of Being just as the Logos is the primordial quality of Being -The Word-. "In the beginning was the word and the word was with God and the word was God".

The form of the Patriarchal Master is on the ontic level of form. The mind knows ontic form. The direct knowing of our awareness knowing the Being of the Guru is on the ontological level of existence. Awareness alone knows Being and awareness knows the Being of form. Awareness knows the direct experience of Being as the luminous Guru. The experience of the Patriarchal Master is on the ontic level of form and the experience of the presence of the Guru is on the ontological level of Being. To confuse these two dimensions of experience of the level of mind and the level of awareness and the ontic level and the ontological level is a source of suffering and bewilderment.

There is the way of the mind knowing form, and there is the way of awareness knowing Being. These are the two different dimensions of knowing. These two ways of knowing can be integrated.

Our mind can know the form of human beings and our awareness can experience the Being of the form of human beings. Our mind can experience the form of a person and our awareness can experience the presence of the Guru within human beings. Our mind can experience the form of a collective group of human beings, and our awareness can experience the presence of Being within the group of beings and as the group of beings. Our awareness can experience the Guru within the Being of a group of people, and as the Being of a group people. The experience of the Guru can be both personal and collective. The guru is 
not only a personal experience, but is also a collective experience of Being.

In the drama of self- liberation we have the power of awareness and the power of Being to experience the field of the guru within our own body and within the body of the world. We can feel through our awareness and directly experience the guru within the baby, within the mother, within the family, and within all other human beings.

\section{It is Simply Not true that the Patriarchal Master Alone Embodies the Guru!}

Many eastern philosophical traditions maintain the illusion that the Patriarchal Master alone is the Person who embodies the inner guru. Many Buddhists and Hindus experience the illusion that the Patriarchal Master alone is the self- manifestation of the universal light and luminous knowing of Being. This is a myopic and political vision of power and status. This is not the truth of the Ontological Guru. This is what Dzogchen calls Ma Rigpa. Ma Rigpa means ignorance of the direct knowing of Being. There is collective Ma Rigpa and there is collective Rigpa.

In truth we all embody the innermost Guru of luminous Being who is the manifestation of the universal light of Being, and the luminous knowing of Being. The very same Being is within all human Beings. This manifestation of the Guru is the source of Equality Consciousness and Equal Vision. This manifestation of the Guru is the source of Egalitarian Life and Social Political System. The Guru is the source of self-liberation within everyone. The Guru cannot be institutionalized. The Guru selfliberates us from the Master Slave relationship, liberates us from the 
Lordship Bondage drama and liberates us from spiritual domination and spiritual submission.

True self liberation is not self- liberation through spiritual submission to spiritual domination. Spiritual submission to spiritual domination is simply submission to domination. The Guru self-liberates us from the Patriarchal Master who thinks they have absolute knowledge. The Patriarchal Master often dominates through obedience and submission. Self- liberation through submission serves domination and not selfliberation!

\section{The Equation of Guru and Patriarchal Master Is Destructive of Equality Consciousness}

In the bewildering "equation" of the Patriarchal Master and the Primordial Guru being the same person, there is the corresponding destruction of Equality Consciousness and Equal Vision. In the religious context that presents the merging of the Primordial Guru and the Patriarchal Master, there is the corresponding co-relational emerging of the Master Slave relationship within this context of the Guru Patriarchal relationship. Hegel masterfully elaborates the Patriarchal Master relationship as the Master Slave relationship and as a relationship of dominance and submission, of Lordship and Bondage. This spiritual relational life of lordship and bondage is not Equality Consciousness or Equal Vision. The drama of lordship and bondage is not the path of Egalitarian life.

For many, many persons the drama of spiritual lordship and spiritual bondage is their only experience of a spiritual religious path. It takes authentic courage to see into, and through the Master Slave relationship of Lordship and Bondage. To think, to really think that self- liberation is 
experienced through lordship and bondage is to be actually lost in and consumed in the Master Slave configuration of Being.

Submission to domination does not give you liberation but submission to domination gives you submission to domination. It is really useful to know that submission to domination is being in and living in a sadomasochistic relational field of Being. So often human mysticism falls into the abyss of masochistic suffering for the sake of divine love and human love.

\section{Illusion and Illusion and Still More Illusion}

In this illusionary context, The Guru becomes the Patriarchal Master and the Patriarchal Master becomes the Guru. There is an illusionary confusion of the two ways of knowing. There is the mind knowing form and awareness knowing Being. When philosophical judgements are made without the foundational distinction between the knowing of mind and the knowing of awareness, there will bewildering and unending confusion about the nature of phenomena, such as the nature of the Guru.

This equation of the Guru as the Patriarchal Master is a source of ontic ontological confusion and bewilderment. This confusion takes place within religion and esoteric religion, both in the east and in the west with the accompanying collective illusion of omnipotence and illusionary omniscience of the Patriarchal Person who is the One who knows absolutely. 


\section{Lordship and Bondage}

Patriarchal Masters never exist by themselves. The Patriarchal Master always and only exists in a relational collective of human beings who play forth with them this mutual drama of lordship and bondage. There is no lordship without the ones who are in bondage. There is no bondage unless there is Lordship. There is the collective mutual field of illusion within the drama of Lordship and submission. This is a field of masochistic suffering for love of the Divine and for the love of selfliberation! This is the delusion of submission.

\section{Intrinsic Opposition}

The Guru is the source and medium of Equality Consciousness and Equal Vision. The Superior Position of Patriarchal Master who is the one who knows Absolutely is destructive of Equality Consciousness and Equal Vision. The Guru is source of Equality Consciousness and the Patriarchal Master who is the one who knows Absolutely are in complete opposition to one another. The union of these two dimensions of knowing is intrinsically and relationally destructive. These two dimensions actually negate each other and together form a delusionary mixture that fragments the truth of Being. The union of these two dimensions are a source not of liberation but a source of Bondage and the hiding of the essential nature of self- liberation. One dimension is political and the other is ontological. One position is ontic and the other position is ontological. The truth is not simply what we say but what we are.

The union of these two dimensions are the union of Royalty and Spirituality. Royalty is Superiority. Royalty is not Equality Consciousness and is not Equal Vision. The union of Equal Vision and the Patriarchal Institutional Superiority of the Patriarchal One who knows Absolutely is 
intrinsically conflictual and intrinsically destructive to the truth of Being and the sameness of Being and the oneness of Being.

\section{Domination and Submission}

The religious context of the imagined Union of the Patriarchal Master and the Guru results in Authoritarian Domination and requires submission to the drama of Patriarchal Authoritarian Phallic Mythology. This manifestation of Authoritarian Domination not only arises in the Patriarchal Religious context but authoritarian domination also arises in the many various forms of Secular Patriarchal Dictatorship. Such Patriarchal Dictatorship can take place in corporations, in families, in education, in intimate sexual experience, in mothering, in fathering, in education and in living. It can happen even with our pets.

Whenever there is an imagined union of the Guru and the Patriarchal Master there is the self-arising of domination requiring devotion and obedience. This obedience often requires the person or person's giving up of their self- agency and self -direction. This giving up of self- agency and one's own self direction is called obedience and is profoundly masochistic. A person gives up their self- agency and their self- direction in order to become liberated and free. Someone else now possesses and owns their self- agency and their freedom.

Their understanding is that a person gains self-liberation by giving up their freedom of self-agency and self-direction to the Patriarchal Master who is the who is the One who knows absolutely. This is very contracted and perverted understanding of self-liberation. This giving up of selfagency and self-direction is a symbolic action signifying Loyalty to the Patriarchal Master and Patriarchal tradition. 


\section{Deification}

In both secular and religious dictatorships, the Authoritarian Patriarchal Person becomes Deified as the One who knows. This deification of course happens consistently in the Religious and Spiritual context. The Patriarchal One who knows Absolutely becomes Deified by all those who do not know and have desire to know absolutely. This Deification often takes place within our imagined experience of the Patriarchal Person being the Guru or having the qualities of the Guru. In many religious contexts, the metaphor of the Guru also becomes the Beatific One who knows Absolutely.

This Patriarchal view inhabits many monasteries of both the eastern and western traditions. This Lordship Bondage realm dominates many eastern and western monasteries. The abbot becomes the One who knows absolutely. The Lordship bondage drama requires many persons to give up their self-agency under the illusionary cloud of submission to the Patriarchal Master and this submission is called sacred obedience. The Patriarchal Master is considered a Symbolic Function of the Divine.

The vows of celibacy and poverty and obedience all are profound ways of giving up self-agency and self-direction. One would think that selfagency and self- direction are innate and intimate to self-liberation. You cannot have self-liberation without self-agency and self-direction. Egalitarian Social and Political life requires self-agency and self-direction. Monasteries may have good and polite manners, but good and polite manners are not the essence of the Egalitarian life or the Life of selfliberation. Good and polite manners are not in essence ethical life. The Spiritual Rule is also another symbolic expression of the Patriarchal Phallic Father. In some religious traditions, God is an expression of The Supreme Phallic Father As Divinity. 


\section{The Presence of the Guru is Within All Persons}

The primordial Guru is not a person and the primordial Guru is not an entity. The guru is not the Symbolic Phallic Father. The primordial selfillumination of the Guru is within everyone. The truth of the primordial Guru is the process of self- manifestation and self- liberation of Pure Being within in all human beings as the luminous Being of their innermost awareness.

\section{Open Process of Self Illumination}

The Open process of self- illumination and self- revelation of the Purity of Being is in all beings as Being and is the Beatific source of the experience of self -liberation. This revelatory process of luminous Being is the foundational source for Equality Consciousness and Equal vision. This process of Equality Consciousness is the ultimate source of Egalitarian Social Political Experience in the world. This process of Equality Consciousness and Equal Vision is the source of Natural Collective Self liberation. The Guru is the Wisdom dimension of Pure Being. The Guru is a Collective field experience of Wisdom Knowing. The Guru is the Logos. And the Logos is the Guru.

\section{Naturalness of Equality Consciousness}

The Guru's natural self- manifestation of Being is manifested in all beings as their very essence of luminous self. The luminous Being-ness of awareness naturally brings forth Equality Consciousness and Equal vision. The luminous Being-ness of Being Shines forth through all beings as Being. 


\section{Infallibility and Omniscience}

The true essence of the Logos is the true essence of universal Guru. Omniscience and omnipotence is neither Equality Consciousness nor Equal Vision. Equality consciousness and Equal vision self- liberates us. Phenomenologically and existentially omniscience does not exist in the unfolding of the infinity of Being. Wisdom gnosis, wisdom knowing is not omniscience. Knowing Being and the knowing power of Being is not omniscience. Knowing Being is the most ordinary knowledge. A baby can know the Being of the mother and through knowing the Being of the mother knows its own Being. Through the non- conceptual knowing of its own Being, the baby knows Being in and of itself. The felt sense of Being becomes the felt sense of self.

This knowing of Being is non conceptual knowing. This is knowing by 'Being the known'. This direct knowing of awareness is different than the dualistic knowing of mind. The duality of mind is the knowing of the subject and the object. This knowing of mind is the knowing of the form of a subject knowing the form of another -the Object-.

The knowing by Being the Known is the Non- Dualistic knowing of awareness which is the very Being of awareness directly knowing the Being of beings. The Being of awareness Knows the Being of a being by Being Being. There is no otherness in non- conceptual Non Dualistic knowing. There is no object and no objectification. In Non Dualistic knowing the Knower becomes the Known and the Knower is the Known. The knower is Being knowing the Being of another. All Being is the same, Una Voce. The knowing of mind is knowing the dualistic difference between forms of subject and object. The knowing of awareness is knowing the oneness of Being and the indivisibleness of Being between all beings. As The Dakini once said to Dudjom Lingpa "You and I are indivisible". This is the essence and power of Mystical Knowing. 
It is true we can all experience and live in timeless awareness and in time simultaneously and not be all-knowing. We can know the three times. There is the time of the past, and the time of the present and the time of the future and the fourth time which is timeless awareness. Timeless awareness is not omniscience. The facticity of omniscience does not exist within human awareness.

There is no content in the direct knowing of Being. There is the concrete fantasy for wishful thinkers that omniscience is knowing the infinity of Being and the Being of infinity. A human being wishfully considers knowing the infinity of Being and this human being is not Being and neither the Infinity of Being. Being is not a being and Being knows the Being of beings including the Being of the being of the world.

\section{The Illusion of Omniscience}

Omniscience is sometimes thought by some to belong to liberated human beings. Liberated human beings are thought to know within the immediacy of the present moment the infinity of existence. This understanding is a concretization and reification of infinity which field of infinity can never ever be concretized. This concretization makes infinity a thing in a box and a concrete object of knowing. Infinity of Being is no thingness. There is no object of infinity. Mind Knowing the infinity of Being is not Being the infinity of Being. Your mind cannot know infinity of Being. The infinity of Being cannot be known with our mind. The concept of infinity of Being is not Being the infinity of Being. The infinity of Being is Divinity. Being the infinity of Being is not Being an entity. Being the infinity of Being is Being infinite. Being is not a being. Being manifests all beings from within its own Being. Being is not a being! 
Phenomenologically, human omnipotence does not exist in the unfolding of the indeterminateness of infinite potentiality. Omnipotence is the concretization of that which cannot be concretized. The infinite indeterminate nature of pure potentiality of Being cannot be contained in the experience of mind or in the thought of our mind.

\section{Concrete Mind as The Reification of Infinity}

Concrete minds think concretely and conceptually about infinity. Concrete minds reify infinity. Concrete minds believe in the concept of infinity. Believing in the idea is not knowing the actuality of the infinity of Being. Believing is not Being infinity. Believing is not knowing. Omnipotence is a reified aspirational concept which is not in the actuality of human experience. Omnipotence is a mythological "mythic aspiration" that is found in spiritual mythology and archetypal mythology. Omnipotent action is a mythic aspiration that is not phenomenologically or existentially found in human experience. Omnipotence is a phantasmagoric delusion.

\section{Saturated: The Experience of Excess}

When human beings experience and embody a deeply felt sense of omnipotence, they are infused and saturated with the infinite dimension of archetypal manifestation. Such an omnipotent person is saturated by the unassimilated intrusion of the archetypal dimension of existence. This fragmenting experience of saturating omnipotence is a signifier of madness. To touch the experience of the vast power of the infinity of the universe as one's own personal experience, and to experience the infinite power as one's own personal power is to experience extreme excess and saturation. In this realm of extreme excess and saturation there arises 
the saturating madness of the primitive symbolic archetypal energies that can consume and devour intentionality of awareness and the reflection of mind.

Most authoritarian dictators are omnipotent and mad, are possessed and saturated by the archetypal symbolic primitive energies of the infinity of Being. This same madness of the possession and saturation of the archetypal symbolic primitive energies of the infinity of Being possess and saturate the person of Patriarchal Master who is consumed by the archetypal field that permeates his power and position of the One who knows Absolutely. The same madness of the archetypal energies can permeate the field of his disciples that experience the Patriarchal Master as the One who knows absolutely. In this context of the Infinity of Being, the madness of the Master Slave relationship manifests out of this infinite context of domination and submission.

\section{Madness and The Symbolic Dimension}

Lacan relentlessly expressed that the infusion and intrusion of Symbolic dimension would bring forth destructive fragmenting states of the saturated experience of madness and dementedness. The mad person experiences the saturation of the omnipotence of the infinity of Being. Many religious institutions suffer from collective madness of the omnipotence of the infinity of Being.

The experience of omniscience and omnipotence is illusionary. The illusionary experience of omniscience and omnipotence is collective madness reflecting the experience of the infinity of Being and the Being of infinity. In religion and in spirituality, omnipotence and omniscience is often attributed to the Patriarchal one who knows absolutely. This attribution of omnipotence and omniscience is a form of deification of the 
authoritarian personality. This sense of deification permeates the energy field of the One who knows and all of those who do not know. Knowing what? Knowing What! Knowing Absolutely No-thing!

Equality Consciousness reflects the knowing of the oneness and sameness of Being, and the oneness and the sameness of all human Being-ness. In the field of Being there is neither above or below, better or best. There is neither truth or falsity. Pure Being is beyond right or wrong. Pure Being is beyond good or evil. Pure Being is beyond Better or Best. All Being is Pure. All Being is the same. All Being is the Same Una Voce- as Dun Scotus describes.

\section{Absolute Knowing and Transcendental Reality}

Our mind knows the form of the Patriarchal Master who symbolically knows Absolutely. Knowing Absolutely is the symbolic function of the Phallic Father -this is not simply a statement of gender-. As we have discussed knowing absolutely does not exist in our multidimensional reality. Knowing absolutely is reflected and projected into the realm of transcendental knowing. Transcendental knowing is the knowing of nothingness or emptiness. Transcendental knowing knows nothing, nothing what so ever. Transcendental knowing does not know Being. There is no knower of mind in transcendental knowing. There is no knowing of Awareness in Transcendental knowing. Transcendental knowing is beyond phenomena and beyond mind, and beyond the knower. In the transcendental state there is no one, not even you. Transcendental knowing is the knowing of absence. 


\section{Gnosis knowing Being}

Our awareness directly knows Being. Our awareness directly knows the oneness of Being. Our awareness directly knows the the non- duality of Being. Our awareness directly knows the Purity of Being. Our awareness directly knows and experiences the Guru as the self-revelation and self-manifestation of Being. The Dynamic of Being's selfmanifestation and self- revelation is the primordial Guru. The primordial Guru is Alethea in the Heidggerian sense. The experience of the Guru is Being experiencing Being's own Being-ness as wisdom knowingness.

\section{Betrayal and The Transcendental}

The Equation of the ontological Guru as The Singular Ontic Patriarchal Master is a Betrayal of the Purity and Universality of the Presence of the Guru. This tragic equation is a reification and distortion of the nature of the ontological Guru. This equation event lacks the direct perceptual experience of the nature of the Guru and the lack of the non- conceptual perception of the manifestation of the presence of Being.

Transcendental Knowing does not reveal the nature of the primordial Guru as the self- manifestation of Being. The Transcendental path does not experience Being's self-manifestation of phenomena as Luminous Being. The Transcendental path does not experience the logos. The Transcendental path does not experience the ontological Guru. The Transcendental path experiences nothing, absolutely nothing. No one! The Transcendental path is a path of Absence and the knowing of absence. Better said this Transcendental path of absence is Absence. Absence of everything or anything. You can actually know absence. Your own absence of Being is the experience of "Absence". 
The Transcendental path does experience the Patriarchal Master as the one who knows the Transcendental dimension. The Transcendental dimension is considered Absolute Knowing which is knowing absence. The Transcendental Dimension is beyond our mind, beyond phenomena, and beyond experience. The Transcendental dimension is beyond knowing and beyond the knower. The Transcendental dimension is beyond omniscience, as there is nothing to know. And the Transcendental dimension is beyond omnipotence, as there is no one and there is no action.

There is no access to awareness of awareness within the transcendental path. The transcendental path is a mind alone path as is discussed in some detail in the beginning of this paper. What is ontologically funny is that "Knowing Absolutely" in Transcendental language is not knowing whatsoever. There is no knower and there is no knowing in transcendental knowing. Ah, The Dakinis laugh.

As the Dzogchen teacher Longchen Rabjam describes in his great Text "Precious Treasury of the Genuine Meaning," Concrete thinking can block the power of awareness directly knowing Being. Concrete minds love believing what is told to them is the actual truth. They are the believers. Concrete minds do not think and do not enter into the field of awareness. Integrating a concrete mind within the field of awareness is not easy. Concrete thinking loves the One Who Knows Absolutely and who is Authoritarian. Concrete knowers tend to be authoritarian. It is hard for awareness to be experienced and to self- manifest in a concrete mind within an authoritarian context. The transcendental path can transcend and go beyond the concrete mind. The concrete mind dumbs down experience. The transcendental path does not utilize the direct knowing of awareness, the direct knowing of Being. The Transcendental Path is the path of unknowing, absolute unknowing. 


\section{Conclusion}

The Equation of the Guru as the Patriarchal Master and the Patriarchal Master as the Guru is a epistemological betrayal of the universal nature of the Guru. The nature of the Guru is Equality Consciousness and the Nature of the Guru is the Purity of Being. The Nature of the Guru is not a singular form. The nature of the Guru is not a person. The nature of the Guru is the creative compassion of primordial awareness that selfmanifests in all human beings, as all human beings, and as all events.

The singular equation of the Guru and the Patriarchal Master who alone knows absolutely -transcendentally- is a betrayal and distortion of the truth of the Guru and the truth of revelation of Being within everyone, and within all events and within all circumstance and within all phenomena. This equation of Guru and Patriarchal Master profoundly weakens the foundations of Egalitarian Life and weakens the foundational experience of Equality consciousness and Equal Vision.

This betrayal of the truth of the universality of the Guru weakens the natural power of the universal transmission of awareness beyond the singular Person of the Patriarchal Master. The Patriarchal Master is an Institutional Faith event. The true Guru is not a contained event. The true Guru is not an institutional event. The Guru cannot be institutionalized. Being cannot be institutionalized. The true Guru is a profound experience of Being and the Self manifestation of Being. The Guru is the source and medium of Egalitarian Life. The Guru is the source and medium of Equality Consciousness and Equal Vision. Equality Consciousness and Equal Vision is the Ontological basis of Egalitarianism and the Power to bring forth Egalitarian life into social and political life. 
The Patriarchal Master is the truth of the illusion of knowing Absolutely. The Guru is the truth of Alethea, which is the truth of selfrevelation and self-manifestation of Being which is the "Being" all beings and all beings Being completely Equal. Or as Duns Scotus would so often say -Una Voce-. 


\section{References}

Capobianco, Richard (2014) Heidegger's Way of Being, University of Toronto Press.

Karunda, Y (2018) Early Buddhist Teachings, Publisher: Wisdom Publications.

Koppl, H (2008) Establishing Appearances As Divine, Snow Lion Press.

Lingpa, D (2015) The Vajra Essence, Translated by Allan Wallace, Wisdom Publications, Somerville, Ma.

Lopez, Donald (2012) From Stone to Flesh: A Short History of the Buddha, Publisher Chicago: University of Chicago Press.

Longechen Rabjam (2015) Precious Treasury Of Genuine Meaning, Translated by Lama Choman and Sangye Khandro. Berosana Publications, Ashland Oregon.

Jeff Love (2018) The Black Circle, A Life of Alexandre Kojeve, Columbia University Press.

Morris, David (2018) Merleau- Ponty's Developmental Ontology, North Western University Studies In Phenomenology and Existential Philosophy, Northwestern University Press, Evanston, Illnois.

Slavoj Zizek (2006) Lacan: The Silent Partners, Verso Press, London. 